\title{
Redescription of Parantipathes euantha (Pasternak, 1958) (Anthozoa: Antipatharia) from Kurile-Kamchatka Trench
}

\author{
T.N. Molodtsova ${ }^{1}$, F.A. Pasternak \\ ${ }^{1}$ P.P. Shirshov Institute of Oceanology, Nakhimovsky pr. 36, 117218 Moscow, Russia. \\ e-mail: tina@sio.rssi.ru
}

\begin{abstract}
A redescription of the deep-sea antipatharian Parantipathes euantha (Pasternak, 1958) from the Kurile-Kamchatka Trench is provided. P. euantha differs from the species previously reported in the genus by its less densely set pinnules, which are arranged in semispiral groups of three and by its large polyps up to $2.5-3 \mathrm{~mm}$ in transversal diameter. Some details of the microscopical anatomy of $P$. euantha and also the composition and geographical distribution of the genus Parantipathes Brook, 1889 are discussed. The key for 7 species of the genus Parantipathes is provided.
\end{abstract}

KEYWORDS: Schizopathidae, Parantipathes, composition of the genus.

\section{Переописание Parantipathes euantha (Pasternak, 1958) (Anthozoa: Antipatharia) из Курило-Камчатского желоба}

\author{
Т.Н. Молодцова ${ }^{1}$, Ф.А. Пастернак
}

\begin{abstract}
Институт Океанологии им. П.П.Ширшова РАН, Москва, 117218 Нахимовский проспект, 36. e-mail: tina@sio.rssi.ru

РЕЗЮМЕ: Представлено переописание глубоководной антипатарии Parantipathes euantha (Pasternak, 1958) из Курило-Камчатского желоба. P. euantha отличается от прочих видов, ранее отмеченных в составе рода, более редко посаженными пиннулами, расположенными полуспиральными группами по три, и крупными полипами, достигающими 2,5-3 мм в трансверзальном диаметре. Обсуждаются микроскопическая анатомия $P$. euantha, а также состав и географическое распространение рода Parantipathes Brook, 1889. Предложен ключ для определения 7 видов рода Parantipathes.
\end{abstract}

КЛЮЧЕВЫЕ СЛОВА: Schizopathidae, Parantipathes, состав рода.

\section{Introduction}

In his recent revision of the family Schizopathidae Opresko (2002) retained in the genus Parantipathes 5 species: P. larix(Esper, 1790), P. tetrasticha (Pourtales, 1868), P. helicosticha (Opresko, 1999), P. laricides (van Pesch, 1914) and $P$. wolffi Pasternak, 1977. In the course of studying the collections of the P.P. Shirshov Institute of Oceanology RAS and the Zoological Institute RAS it was found that two more species have to be included to the genus Parantipathes. These are P. euantha(Pasternak, 1958) from continental slope of Kurile-Kamchatka Trench originally described in the genus Bathypathes and P. hirondelle Molodtsova, 2006, 
previously reported as $P$. larix from oceanic rises and the continental slope of the North-East Atlantic (Roule, 1905, Gravier, 1921, Grasshoff, 1981, 1985, 1989). A redescription of $P$. euantha (Pasternak, 1958) is provided and the geographical distribution of the genus Parantipathes is discussed.

\section{Material and methods}

The material was collected during the $14^{\text {th }}$ and $45^{\text {th }}$ cruises of RV «Vityaz» in the North Pacific and also by the RV «Novorossiysk» and RV «Novoulyanovsk» to the Sea of Okhotsk. The specimens were initially preserved in $70 \%$ ethanol or in $4 \%$ seawater buffered formalin. All measurements of the corallum were carried out on preserved material. The spines were measured using SEM images as well as light microscopy of the skeleton. The distance between spines was measured between the centers of the bases of adjacent spines of the same longitudinal row; and the height of a single spine was measured between the apex and the center of the base.

\section{Systematic part}

Family Schizopathidae Brook, 1889

Genus Parantipathes Brook, 1889

Diagnosis: Corallum monopodial to very sparsely branched, stem and branches pinnulate Pinnules simple, arranged in six or more rows, and in alternating groups of three or more on either side of the axis. Spines simple, triangular, compressed. Polyps usually $1.6-2.5 \mathrm{~mm}$ in transverse diameter, rarely larger.

Type species Antipathes larix Esper, 1790.

\section{Parantipathes euantha (Pasternak, 1958)}

Bathypathes euantha Pasternak, 1958: 187-191, Fig. 3-6;

non Bathypathes euantha Pasternak, 1976: 48.

Diagnosis: Corallum monopodial and pinnulate. Pinnules simple, slightly curved backwards relative to the front (polypar) side of the corallum, extending out at angles $50^{\circ}$ to $80^{\circ}$ to the direction of stem. Over most of the colony pinnules arranged bilaterally in six rows, those in the lowermost part of the colony arranged in four rows. Along the sides of the stem pinnules arranged in alternating, overlapping, semispiral groups of three each. Spines simple, smooth, rounded at the apex, compressed and triangular in lateral view; $0.07-0.1 \mathrm{~mm}$ tall; arranged in longitudinal rows 5 to 6 visible in lateral view, 3 to 4 spines per millimeter in each row. Polyps elongated, 1.9 to $2.7 \mathrm{~mm}$ in transverse diameter.

Examined material: Holotype Bathypathes euantha Pasternak, 1958 (s/n: P.P. Shirshov Institute of Oceanology RAS): "Vityaz" St. 2078 (44 09' N $148^{\circ} 38^{\prime}$ E) $1080 \mathrm{~m}$.

Redescription: The alcohol-preserved holotype is a colony $32 \mathrm{~cm}$ tall and $5.5 \mathrm{~cm}$ wide, having the appearance of an ostrich-plume broken into several fragments. Length of the largest fragment is $27 \mathrm{~cm}$ (Fig.1A). The color of the stem is dark reddishbrown, almost black, at the base of the colony, changing to red-brownish in the uppermost part. Pinnules are pale-brown, semitransparent. The stem diameter is $1.8 \mathrm{~mm}$ just above the basal plate and $0.7 \mathrm{~mm}$ near the apex of the colony. The lower unpinnulated portion of the stem is $2 \mathrm{~cm}$ long. Along the next $0.5 \mathrm{~cm}$ the bases of broken pinnules, arranged in two bilateral rows, can be traced. Over the following $2 \mathrm{~cm}$ the pinnules are arranged in two bilateral rows and in the next $3.5 \mathrm{~cm}$ they are arranged in four bilateral rows, two on each side of the axis. On the remaining part of the colony the pinnules are arranged in six rows, three on each side (Fig. 1B, C). Along the sides of the stem the pinnules are also arranged in alternating overlapping groups. The groups consist of three pinnules along the main part of corallum and two pinnules at the basal part of corallum. Groups of two also occur sporadically among groups of three along the whole length of the colony. The distance between pinnules of the same group ranges from 0.6 to $1.33 \mathrm{~mm}$, but is usually 0.8 to $1.0 \mathrm{~mm}$. The pinnules in each group follow a clear semispiral arrangement with the front or anterior pinnule of each group lowermost on the axis and the posterior pinnule most distal - relative to the direction of the stem. The groups on one side of the axis somewhat alternate with those on the other side such that the first pinnule of each group (the most anterior one) on the right side of the axis when looking at the front (polyp) side of the corallum is always situated between the second and third pinnule of the group on the opposite side of the stem. Irregularities in the arrangement of pinnules on one side of the axis (when one or even two pinnules are missing in a group) result in irregularities on the other side. Usually each semispiral group covers a distance of 2.25 to $5 \mathrm{~mm}$ along the stem and there are 2.2 to 2.7 groups per centimeter on each side of the colony, resulting in a total of 12 to 14 pinnules per 1 centimeter.

The distal angle between the pinnules and the stem is $50^{\circ}$ to $80^{\circ}$. Each pinnule has the form of a 

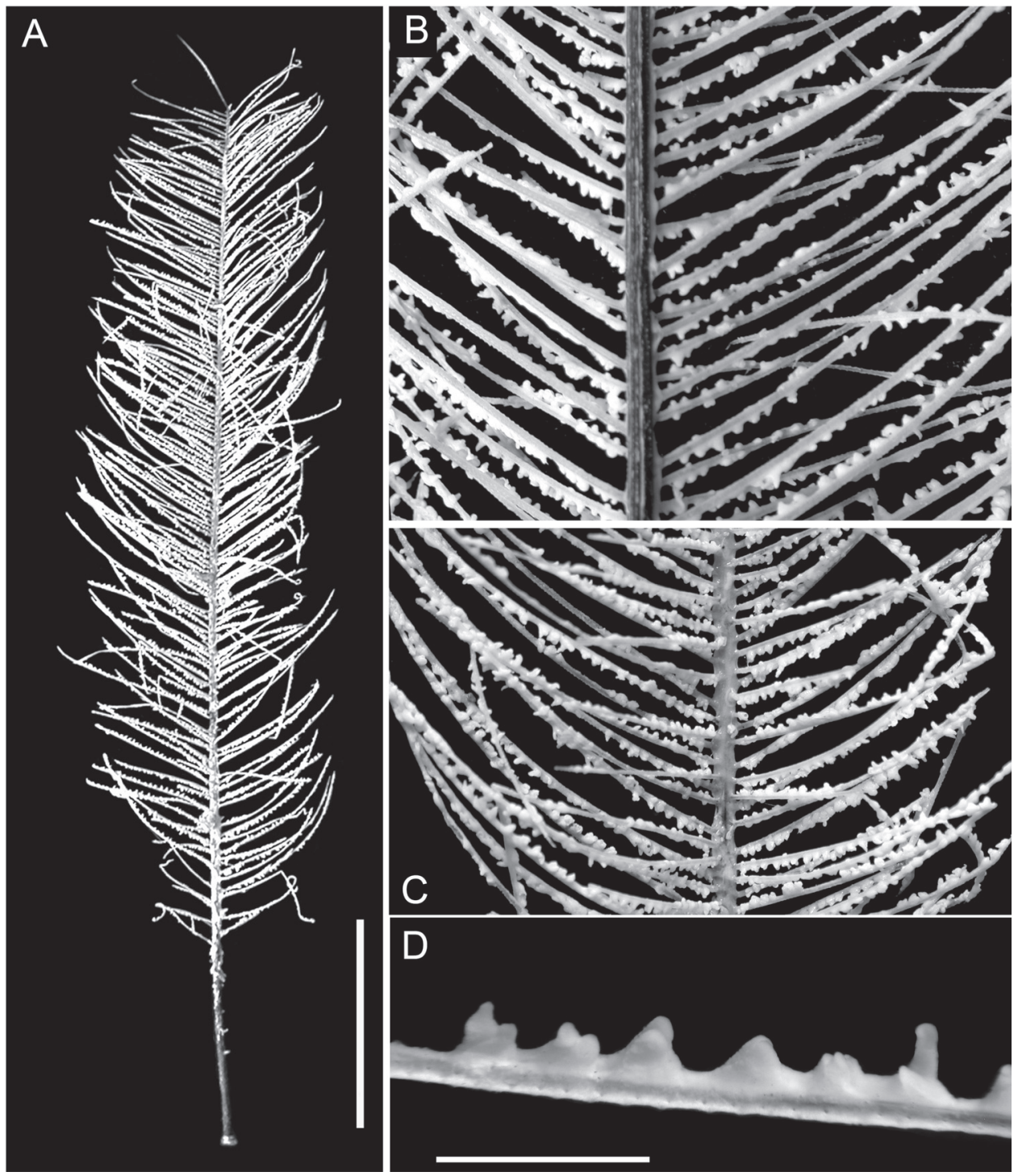

Fig. 1. Parantipathes euantha (Pasternak, 1958), holotype:

A - entire corallum, scale - $5.5 \mathrm{~cm}$; B - closer view of the corallum, abpolypar side; $\mathrm{C}$ - closer view of the corallum, polypar side; D - polyps, scale $2 \mathrm{~mm}$.

Рис. 1. Parantipathes euantha (Pasternak, 1958), голотип:

А - внешний вид колонии, масштаб - 5.5 см; В - внешний вид колонии при большем увеличении, абполипарная сторона; C — внешний вид колонии при большем увеличении, полипарная сторона; D — полипы, масштаб 2 мм.

flat arch in that it is slightly curved upwards and backwards. Often pinnules are broken at their distal end. Usually the length of pinnules of the anterior rows is less then that of the posterior rows. The maximum length of the posterior pinnules is $3.8 \mathrm{~cm}$ the length of the anterior ones is not more than 2.8 $\mathrm{cm}$. The basal diameter of the pinnules ranges from 0.22 to $0.3 \mathrm{~mm}$.

The spines (Fig. 2) on the pinnules are simple, smooth, slightly rounded at the apex, distinctly compressed from the sides and triangular in lateral view. They are usually set at a right angle to the 

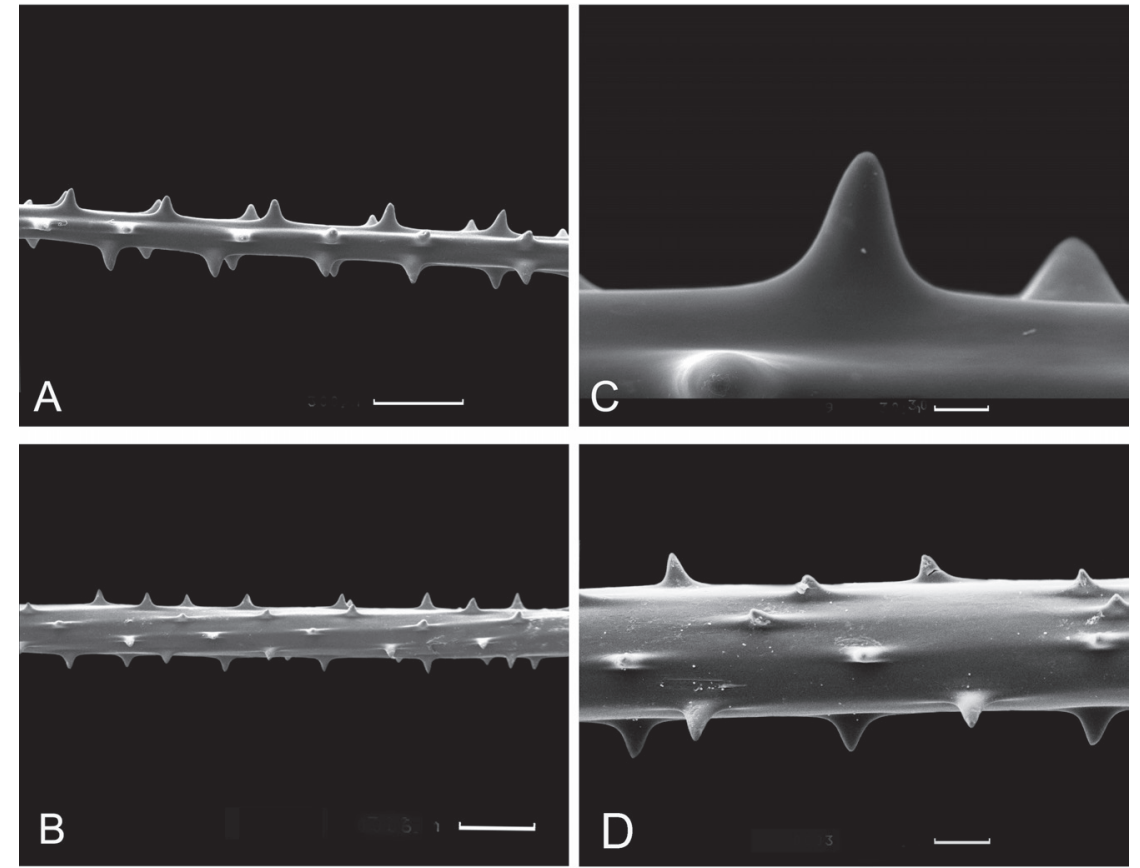

Fig. 2. Parantipathes euantha (Pasternak, 1958), holotype:

A - spines on the tip of pinnule; B - close view of the spine; C, D - spines in the middle part of the pinnule. Scale: A, B $-300 \mu \mathrm{m} ; \mathrm{C}-30 \mu \mathrm{m} ; \mathrm{D}-100 \mu \mathrm{m}$.

Рис. 2. Parantipathes euantha (Pasternak, 1958), голотип:

A - шипы в апикальной части пиннулы; В - шип при большем увеличении; C, D - шипы в средней части пиннулы. Масштаб: А, В - 300 мкм; C - 30 мкм; D - 100 мкм.

direction of the axis or are slightly inclined distally or proximally. Usually all spines around the axis have the same height and there is only a very slight, if any, difference between abpolypar and polypar spines. As measured from midpoint of the base to the apex, they are $0.07-0.1 \mathrm{~mm}$ high. The pinnular spines are arranged in longitudinal rows, five to six of which are visible in a lateral view. The distance between adjacent spines in each row is rather variable $(0.2-$ $0.56 \mathrm{~mm}$, mostly $0.27-0.4 \mathrm{~mm}$ ). On average there are usually 3-3.5 spines per millimeter in each row.

Polyps (Fig. 1B-D) are arranged uniserially on the pinnules, where they have the usual transversally elongated form, with three distinct parts corresponding to three pairs of tentacles, typical for the genus. The few polyps seen on the main stem occur mostly on the lower parts of the corallum and primarily on one side of the axis, which is here referred to as the front side of the corallum. They are rounded, without any traces of segregation into three parts. Pinnular polyps can occur on the front, upper or lower sides of pinnules, with the polyps of adjacent pinnules generally facing in opposite directions. Often the polyp row changes position along one pinnule in such a way that at the base the polyps are arranged on the front or upper side and distally they are shifted to the lower side of the pinnule. The polyps are mostly 1.6 to $2.7 \mathrm{~mm}$ (range $1.47-2.95 \mathrm{~mm}$ ) in transversal diameter. The oral cone is not very distinct, coneshaped or slightly elongated transversally, and up to $0.34 \mathrm{~mm}$ high. In the alcohol-preserved material the tentacles are 0.3 to $1.0 \mathrm{~mm}$ long depending on degree of contraction; on average, they are 0.5 to $0.7 \mathrm{~mm}$ long. The interpolypar space ranges from 0.34 to $1.23 \mathrm{~mm}$ (mainly 0.5 to $1.0 \mathrm{~mm}$ ) and usually there are 2.5 to 3.3 polyps per centimeter. Generally there are not more than 10 polyps per pinnule. Usually the smallest polyps occur near the base of the pinnules and the most elongated ones are on the distal part of the pinnules.

Microscopic anatomy: The only specimen of the species was alcohol-preserved, so not many details are discernible in microscopical sections.

The tentacles (Fig. 3B) are rounded or slightly elliptical in cross-section. Distally near the tip, the epidermis is $50-63 \mu \mathrm{m}$ in thickness with a large number of high flagellate supporting cells, scattered mucus cells and plenty of cnidocysts, which are 
mainly spirocysts $23 \times 4 \mu \mathrm{m}$ in dimension, and packed in batteries, about $40 \mu \mathrm{m}$ in diameter, evenly arranged along the perimeter of the tentacle. Proximally, the epidermis of the tentacles does not exceed 25-30 $\mu \mathrm{m}$. A stripe of spirocyst batteries remains on the inner face even in lower regions of each tentacle, but the greatest number of spirocysts is concentrated in the upper third. The gastrodermis of the tentacles is 28 to $38 \mu \mathrm{m}$ thick. It consists of large vacuolated gastrodermal cells of general anthozoan structure and scattered mucus cells. The mesoglea is $2-4 \mu \mathrm{m}$ thick distally, and increases to 6-8 $\mu \mathrm{m}$ proximally.

The oral cone in cross-section appears round or slightly elongated transversally (Fig. 3A, C). The epidermis is $15-38 \mu \mathrm{m}$ thick and has the same structure as the epidermis of the tentacles, with scattered batteries of spirocysts that seem to be continuations of corresponding stripes of the tentacles. The mesoglea is $5-6.5 \mu \mathrm{m}$ thick on the transverse margins and $2-4 \mu \mathrm{m}$ on the rest of the perimeter. The gastrodermis is $15-25 \mu \mathrm{m}$. In the actinopharynx the epidermis is $45-80 \mu \mathrm{m}$ thick and consists of tall supporting cells with a relatively large number of evenly scattered mucus cells (Fig. 3C). The actinopharynx is folded without traces of siphonoglyphs. The mesoglea is $1-4 \mu \mathrm{m}$, and the gastrodermis, which has the same structure as the gastrodermis of tentacles, is $5-15 \mu \mathrm{m}$.

The bodywall epidermis is generally very thin $(5-10 \mu \mathrm{m})$, with a small number of mucus cells and widely scattered spirocysts, but reaches up to $30 \mu \mathrm{m}$ near the axis. The mesoglea is generally $5-9 \mu \mathrm{m}$ (but up to $20 \mu \mathrm{m}$ near the axis). In the studied material there were no traces of an "interzooidal septum" such as that described by van Pesch (1914) for Schizopathes affinis. The gastrodermis is generally 13 to $15 \mu \mathrm{m}$ thick but near the axis it can be as thick as $75 \mu \mathrm{m}$.

The mesenteries, 6 primary and 4 secondary ones, are very thin and often hardly distinguishable. The secondary mesenteries are clearly visible in the middle part of the oral cone only. They are generally 2.5 to $7.5 \mu \mathrm{m}$ but in some places reach up to 10 and even $15 \mu \mathrm{m}$ thick. In the studied material no traces of muscle fibers were found. Mesenterial filaments are developed on the transversal primary mesenteries only and have a general appearance of the simple cord region of other Anthozoa. Here there are plenty of mucus cells and a number of nematocysts (apparently b-rabdoids) $38-44 \times 7.5-10 \mu \mathrm{m}$ in size (Fig. 3E). Oocysts (Fig. 3D) are round or slightly elongated along the mesogleal lamella, 75-125 $\mu \mathrm{m}$ in diameter, and usually arranged on one side of the mesentery only. They are enclosed into thin mesogleal capsule up to $0.5 \mu \mathrm{m}$ thick.
Remarks: Pasternak (1976) identified as Bathyanthus euantha three specimens collected from the vicinity of Unimak Island (Alaska): "Vityaz" St. $6132\left(53^{\circ} 48.0^{\prime} \mathrm{N} 163^{\circ} 34.0^{\prime} \mathrm{W}\right) 1040 \mathrm{~m}$. However after a closer examination of that material, and additional material from the Sea of Okhotsk, we had to conclude that these three specimens represent fragments of a large branching colony and undoubtedly represent a new species closely related to P. tetrasticha (Pourtales, 1868). However the fragments we have in the collection are rather small to see the pattern of branching which would be to adequately describe the species. Consequently, the holotype of $P$. euantha represents the only known specimen of this species, and future investigations of material from the region are badly needed to understand the range of intraspecific diversity.

Comparison: P. euantha can be easily distinguished from other species of the genus (Table 1). It differs from $P$. larix by the clear alternative arrangement of semispiral groups of pinnules along the axis, lower density of the pinnules along the axis (12-14 pinnules per centimeter in $P$. euantha and 21 per centimeter in $P$. larix) and smaller distal angle between the pinnules and stem $\left(50-80^{\circ}\right.$ vs. $90^{\circ}$ in P. larix) (Opresko, BaronSzabo, 2001). In $P$. larix pinnules can be also arranged in semispiral groups, but they are not so regular as in $P$. euantha, and the colony of $P$. larix has a more brush-like appearance.P. euantha can be differentiated from $P$. tetrasticha by its shorter interpinnular distance which seldom exceeds $1 \mathrm{~mm}$ in $P$. euantha and is usually about $2 \mathrm{~mm}$ in $P$. tetrasticha (see Opresko, 1972). Also, P. tetrasticha has a denser polyp arrangement (four to five polyps per centimeter compared with 2.5 to 3.3 per centimeter in $P$. euantha) and more spines per millimeter in each axial row (4 to 7 , mostly 5-6, and 3 to 3.6 , respectively).

In $P$. helicosticha (Opresko, 1999) and $P$. hirondelle Molodtsova, 2006 the pinnules are arranged in semispiral groups as in $P$. euantha, but the general number of pinnules in each group can exceed three (up to five and up to four, respectively). The distal angle between the pinnules and the stem in P. helicosticha is about $90^{\circ}\left(50^{\circ}\right.$ to $80^{\circ}$ in $P$. euantha $)$. In $P$. helicosticha there are four groups per centimeter on each side of the stem and in P. hirondelle this value can be up to five, whereas in $P$. euantha there are 2.2-2.7 groups of pinnules per centimeter. The pinnules of $P$. helicosticha and $P$. hirondelle do not exceed $2 \mathrm{~cm}$ in length, whereas they are mainly 2.5 $3.4 \mathrm{~cm}$ in $P$. euantha. The spines in P. helicosticha are seldom less $0.1 \mathrm{~mm}$, and at the distal end of the pinnules they can be as high as $0.2 \mathrm{~mm}$, and there are three to four longitudinal rows of spines visible from the side of pinnule. In contrast, the spines in $P$. euantha are $0.07-0.1 \mathrm{~mm}$ tall and there are 5-6 rows visible in lateral view. In $P$. hirondelle the pinnular spines are also small, but they are not compressed as 


\begin{tabular}{|c|c|c|c|c|c|c|c|c|c|}
\hline 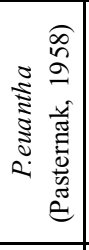 & 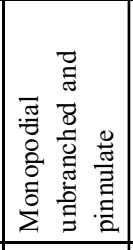 & 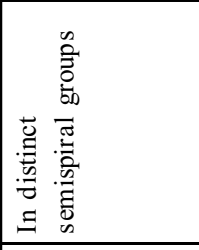 & $\begin{array}{l}0 \\
\dot{0} \\
\text { ì } \\
\text { in }\end{array}$ & $\begin{array}{l}\infty \\
\dot{m} \\
0 \\
\equiv \\
\equiv\end{array}$ & $\begin{array}{l}m \\
\stackrel{1}{1} \\
\text { } \\
0\end{array}$ & $\begin{array}{l}m \\
0 \\
0 \\
0\end{array}$ & 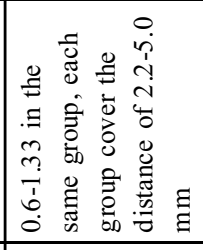 & $\begin{array}{l}n \\
\dot{f} \\
\dot{f}\end{array}$ & $\underset{\stackrel{I}{I}}{\stackrel{ \pm}{\prime}}$ \\
\hline 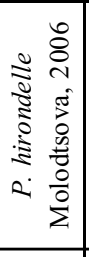 & 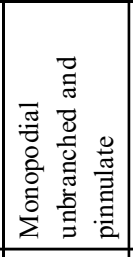 & 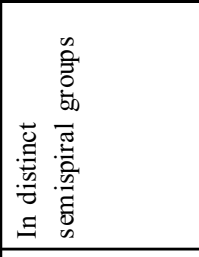 & $\begin{array}{l}0 \\
\dot{0} \\
1 \\
1\end{array}$ & $\begin{array}{l}\stackrel{i}{i} \\
\dot{0} \\
\dot{b}\end{array}$ & \begin{tabular}{l}
$\infty$ \\
\multirow{1}{1}{} \\
$\stackrel{1}{0}$ \\
$\stackrel{0}{0}$
\end{tabular} & $\begin{array}{l}+ \\
\stackrel{2}{2} \\
\stackrel{2}{s}\end{array}$ & 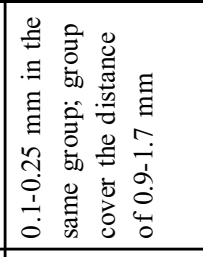 & $\frac{\circ}{\alpha}$ & $\begin{array}{l}\stackrel{q}{+} \\
\text { m }\end{array}$ \\
\hline 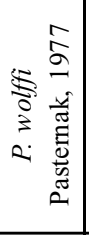 & 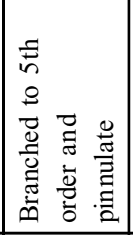 & 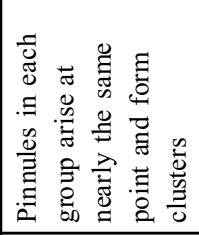 & \&̊ & $\begin{array}{l}n \\
\text { ri } \\
\stackrel{i}{i}\end{array}$ & 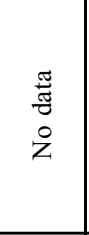 & $\begin{array}{l}n \\
\stackrel{0}{N} \\
\sim\end{array}$ & 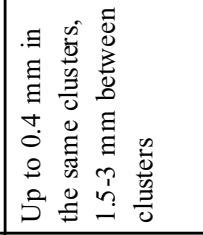 & 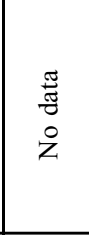 & $\begin{array}{l}\frac{\pi}{\tilde{J}} \\
\text { Z } \\
\text { z }\end{array}$ \\
\hline 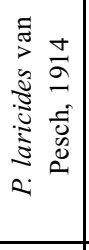 & 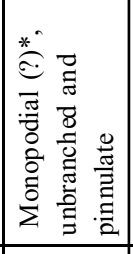 & 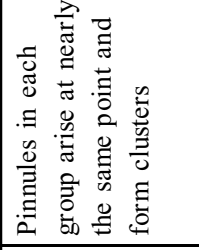 & $\begin{array}{l}0 \\
\vdots \\
\frac{1}{6} \\
0\end{array}$ & 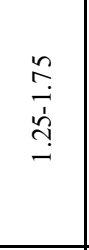 & $\begin{array}{l}\frac{\pi}{\tilde{J}} \\
\text { ¿ } \\
\text { z }\end{array}$ & $\begin{array}{l}m \\
\stackrel{2}{ } \\
2 \\
s\end{array}$ & 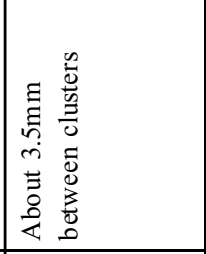 & $\begin{array}{l}\frac{\pi}{\tilde{J}} \\
\text { O } \\
\text { z }\end{array}$ & $\begin{array}{l}\frac{\pi}{\tilde{J}} \\
\text { O } \\
\text { Z }\end{array}$ \\
\hline 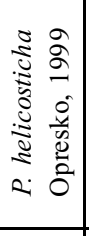 & 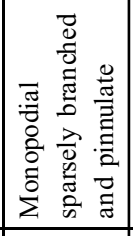 & 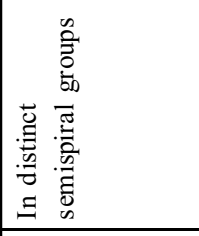 & \&̊ & 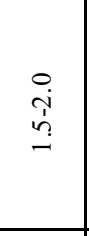 & ชู & 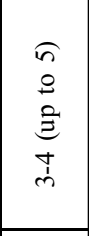 & 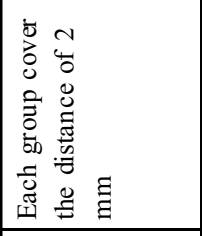 & $\stackrel{*}{*}$ & $\begin{array}{l}\stackrel{*}{*} \\
\stackrel{*}{?} \\
?\end{array}$ \\
\hline 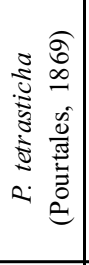 & 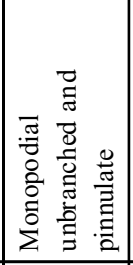 & 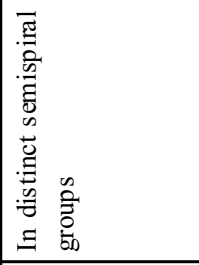 & $\begin{array}{l}0 \\
\vdots \\
\vdots \\
0\end{array}$ & 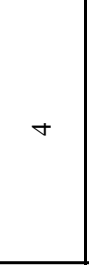 & $\begin{array}{l}n \\
\vdots \\
\vdots \\
\vdots \\
0\end{array}$ & $\stackrel{+}{\circ}$ & 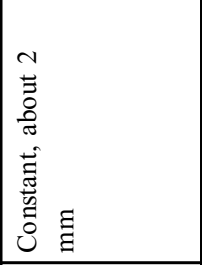 & 俈 & $\begin{array}{l}0 \\
i \\
0 \\
\equiv\end{array}$ \\
\hline 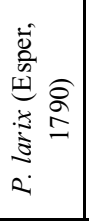 & 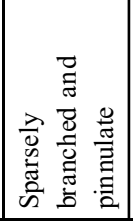 & 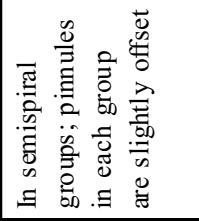 & 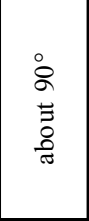 & $\begin{array}{l}\text { I } \\
0 \\
\vdots \\
0 \\
0\end{array}$ & 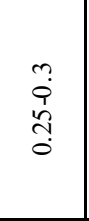 & 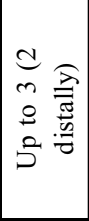 & 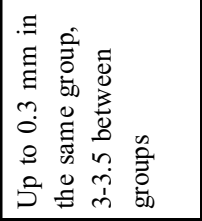 & r & $\vec{\sim}$ \\
\hline & 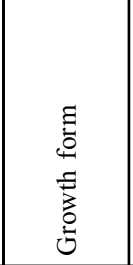 & 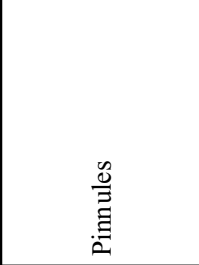 & 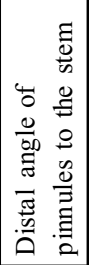 & 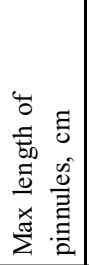 & 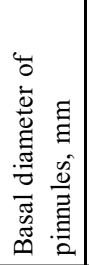 & 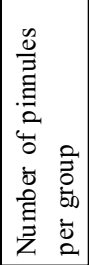 & 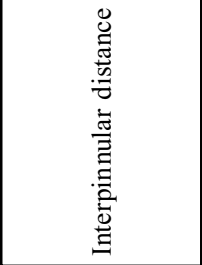 & 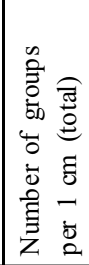 & 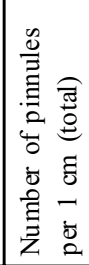 \\
\hline
\end{tabular}




\begin{tabular}{|c|c|c|c|c|c|c|c|c|c|}
\hline 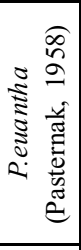 & 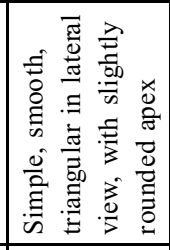 & $\begin{array}{l}\overrightarrow{0} \\
0 \\
\vdots \\
0 \\
0\end{array}$ & $\begin{array}{l}0 \\
n \\
0 \\
1 \\
\\
0\end{array}$ & 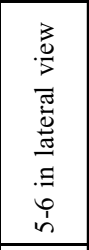 & 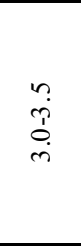 & 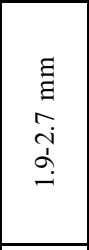 & 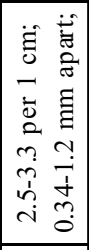 & \begin{tabular}{|l|} 
\\
\\
$\Xi$ \\
0 \\
$o$ \\
$\stackrel{0}{-}$ \\
\end{tabular} & 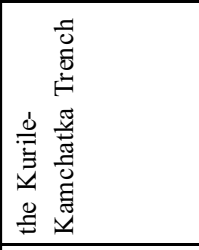 \\
\hline 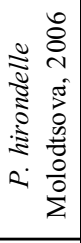 & 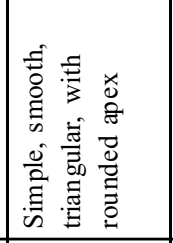 & 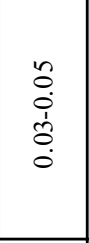 & $\begin{array}{l}1 \\
\vdots \\
⿱ 亠 \\
0 \\
0 \\
0\end{array}$ & 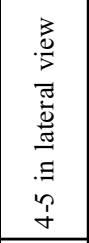 & $\frac{\circ}{\alpha}$ & $\begin{array}{l}\Xi \\
\Xi \\
\stackrel{\Xi}{I} \\
\stackrel{I}{-}\end{array}$ & 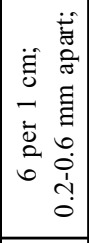 & 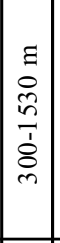 & 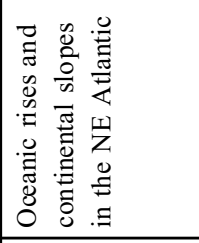 \\
\hline 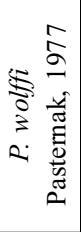 & 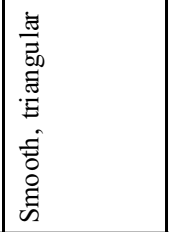 & $\begin{array}{l}\hat{0} \\
0 \\
0 \\
\hat{1} \\
0 \\
0\end{array}$ & 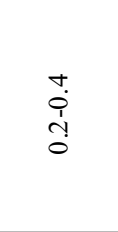 & 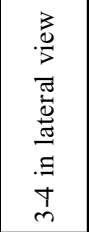 & $\begin{array}{l}\text { 㺃 } \\
\text { ¿ } \\
\text { Z }\end{array}$ & $\begin{array}{l}\text { 㺃 } \\
\text { ¿ } \\
\text { Z }\end{array}$ & $\begin{array}{l}\text { 㺃 } \\
\text { 号 }\end{array}$ & $\begin{array}{l}\Xi \\
0 \\
\stackrel{d}{=}\end{array}$ & 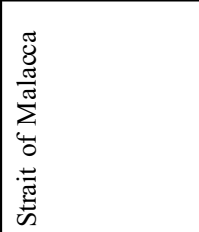 \\
\hline 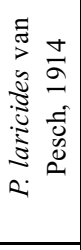 & 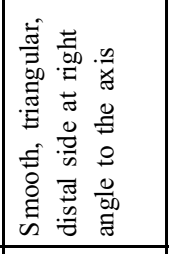 & 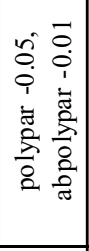 & $\stackrel{\text { ڤn }}{0}$ & 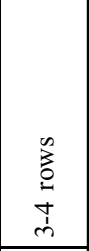 & 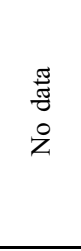 & 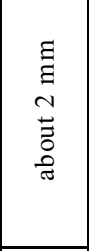 & 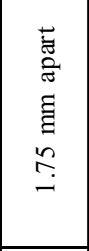 & 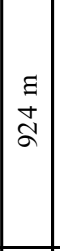 & 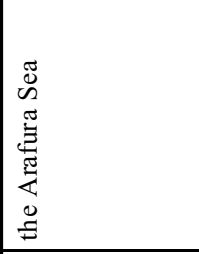 \\
\hline 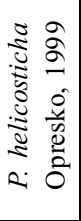 & 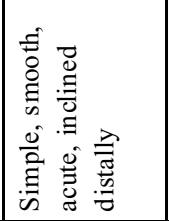 & $\begin{array}{l}\text { Î } \\
\stackrel{1}{1} \\
\stackrel{1}{*}\end{array}$ & $\begin{array}{l}\text { 苋 } \\
\text { Z } \\
\text { Z }\end{array}$ & 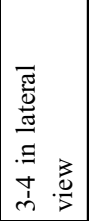 & $\stackrel{n}{\vec{r}}$ & 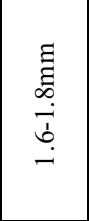 & 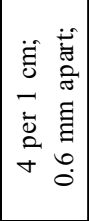 & 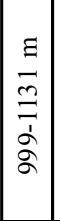 & 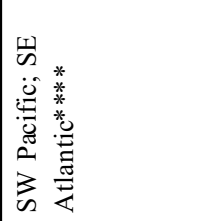 \\
\hline 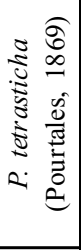 & 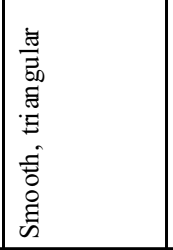 & $\begin{array}{l}\text { oे } \\
0 \\
\hat{0} \\
\text { Oे. } \\
\dot{0}\end{array}$ & $\begin{array}{l}\stackrel{1}{0} \\
\dot{1} \\
\stackrel{1}{0}\end{array}$ & 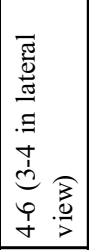 & $\stackrel{\infty}{+}$ & $\begin{array}{c}\text { E } \\
\underline{\Xi} \\
\sim \\
\text { i }\end{array}$ & 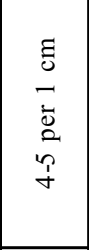 & 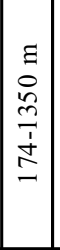 & 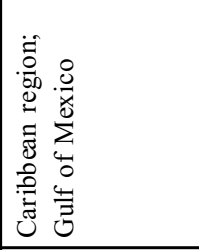 \\
\hline \multirow[t]{2}{*}{ 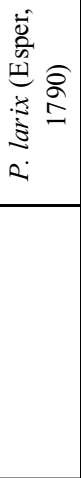 } & 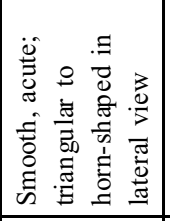 & $\begin{array}{l}0 \\
0 \\
0 \\
0 \\
0 \\
0 \\
0 \\
0 \\
0 \\
0 \\
0\end{array}$ & $\begin{array}{l}\hat{n} \\
\hat{1} \\
\hat{1} \\
0\end{array}$ & 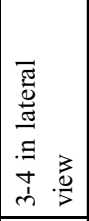 & $\begin{array}{l}n \\
\ddot{y}\end{array}$ & 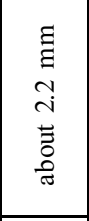 & $\begin{array}{l}\text { 莺 } \\
\stackrel{0}{z}\end{array}$ & 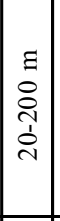 & 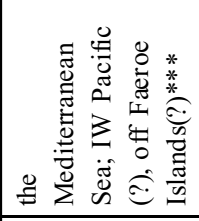 \\
\hline & 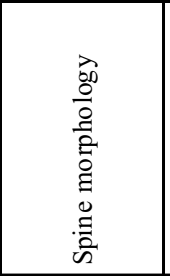 & 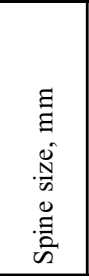 & 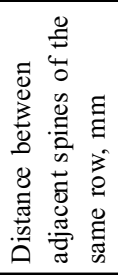 & 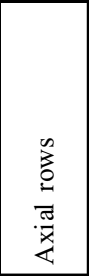 & 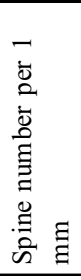 & 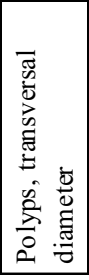 & 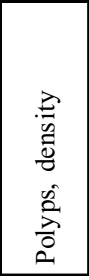 & 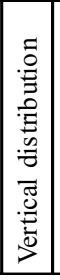 & 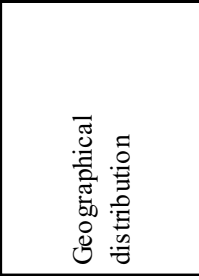 \\
\hline
\end{tabular}




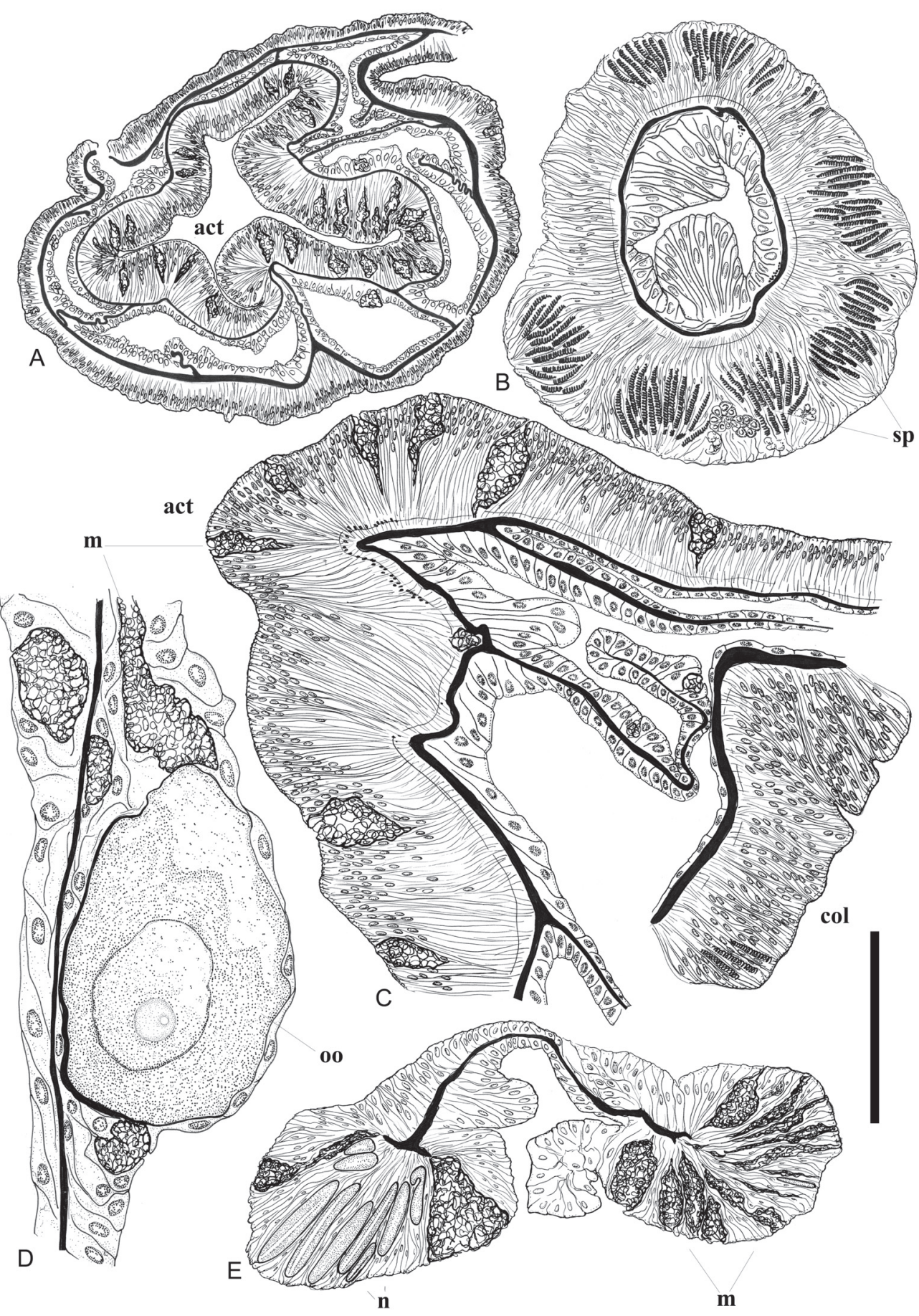




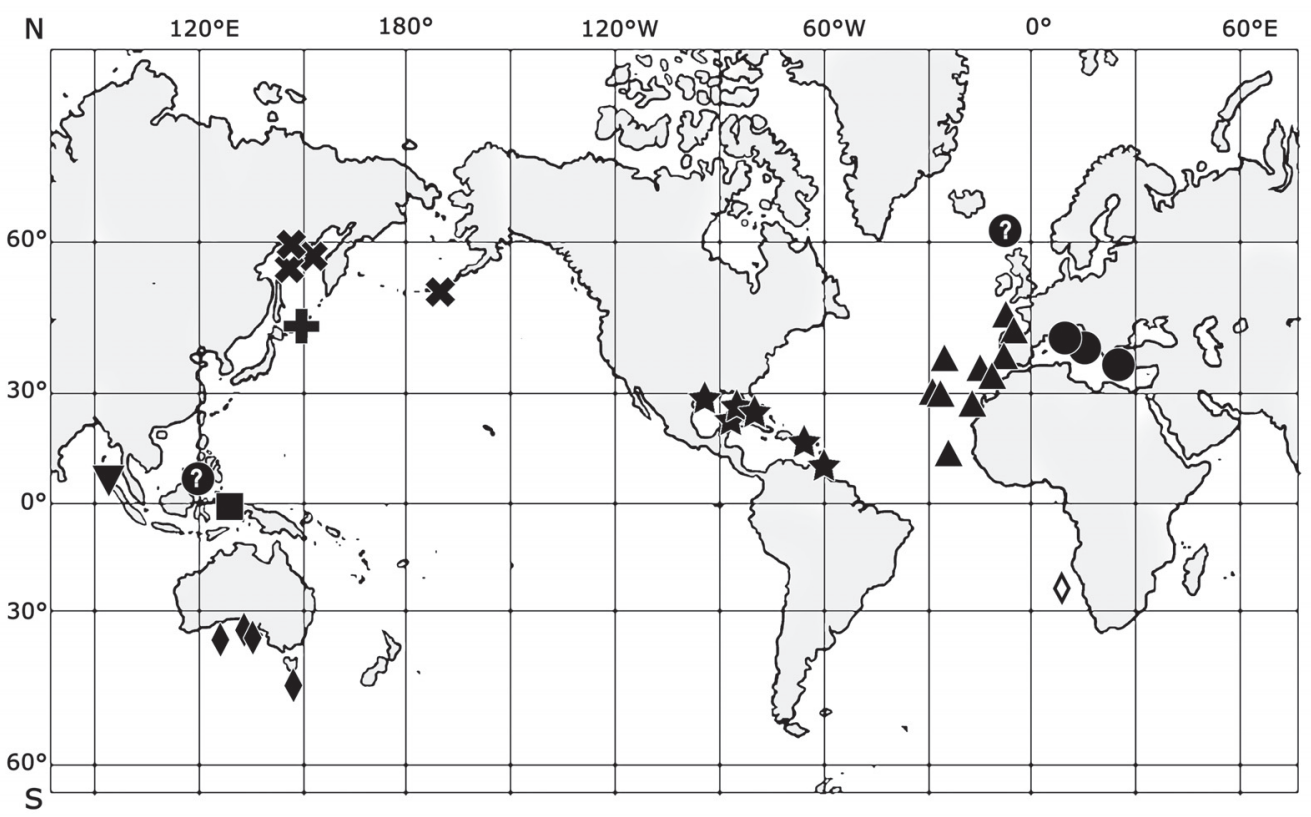

Fig. 4. Geographical distribution of the species of the genus Parantipathes:

- - P.larix, $₫-P$. tetrasticha, $\diamond, \diamond-P$. helicosticha, $\mathbf{\square}-$ P. laricides, $\nabla-P$. wolffi, $\mathbf{\Delta}-P$. hirondelle, + - P. euantha, $*$ - P. sp. , ? — doubtful records; filled signs — data from the literature, opened signs — original data. Рис. 4. Географическое распростронение видов рода Parantipathes:

- - P.larix, $\downarrow-P$. tetrasticha, $\diamond, \diamond-P$. helicosticha, $\mathbf{\square}-$ P. laricides, $\nabla-P$. wolffi, $\mathbf{\Delta}-P$. hirondelle, + - P. euantha, $\boldsymbol{*}$ - P. sp., ? - сомнительные определения; заштрихованные знаки - литературные данные, контурные знаки — оригинальные данные.

in P. euantha and they are very closely arranged, resulting in 9-10 spines per $1 \mathrm{~mm}$; in comparison there are $3-3.5$ per $1 \mathrm{~mm}$ in $P$. euantha.

In both $P$. laricides and $P$. wolffi the pinnules are arranged in groups of two or three, but the pinnules do not follow a semispiral pattern; instead, they are attached to the stem at the same level (sometimes with small hiatus of $0.4 \mathrm{~mm}$ in $P$. wolffi). Also, these species have fewer rows of the spines (three rows visible from the side in contrast to five to six rows in $P$. euantha). In P. laricides there is a clear difference between polypar $(0.055 \mathrm{~mm})$ and abpolypar $(0.01$ $\mathrm{mm}$ ) spines whereas in $P$. euantha the difference between polypar and abpolypar spines can be hardly noticed (the total range is 0.07 to $0.1 \mathrm{~mm}$ ).

\section{Discussion}

Thus, seven species can be referred to the genus Parantipathes: P. euantha (Pasternak, 1958), P. helicosticha Opresko, 1999, P. hirondelle Molodtsova, 2006, P. larix (Esper, 1790), P. laricides van Pesch, 1914, P. tetrasticha (Pourtales, 1868) and $P$. wolffi Pasternak, 1977. The main characters of all the species referred to the genus are summarized in the Table 1. Six species have a rather uniform corallum (monopodial or very sparsely branched) and pinnulation pattern consisting of semispiral groups of three or more. In a contrast to all other species of the genus, $P$. wolffi has a densely branched (up to $5^{\text {th }}$ order) corallum and a rather

Fig. 3. Parantipathes euantha (Pasternak, 1958), holotype:

A - cross-section of polyp; B - cross-section of tentacle; C - section of actinopharynx; D, E - section of fertile mesentery. act - actinopharynx; col - column wall, $m$ - mucus cells; $n$ - nematocysts; oo - oocyte; $s p$ - batteries of spirocysts. Scale: A $-800 \mu \mathrm{m} ; \mathrm{B}-240 \mu \mathrm{m} ; \mathrm{C}, \mathrm{E}-100 \mu \mathrm{m}$; D $-40 \mu \mathrm{m}$.

Рис. 3. Parantipathes euantha (Pasternak, 1958), голотип:

A — поперечный срез полипа; В — поперечный срез щупальца; C — поперечный срез через глотку; D, E — срез мезентерия с гонадами. Масштаб: А - 800 мкм; В - 240 мкм; С, E - 100 мкм; D - 40 мкм. act — глотка; col - стенка тела, $m$ - слизистые клетки; $n$ - нематоцисты; oо - ооциты; $s p$ - батареи спироцист. 
irregular pinnulation pattern. The branching pattern, length and arrangement of pinnules make $P$. wolffi to look very close to Taxipathes which also has pinnules $2 \mathrm{~cm}$ long and three per semispiral. There is no information about the polyps of $P$. wolffi. However, despite that, in general, the form of the polyps in all the other species seems to be rather constant and characteristic to the family: i.e., elongated transversally, with six primary and four secondary mesenteries (Opresko, 2002). As can be seen in the table, the size and the density of the polyps in the genus Parantipathes varies a lot: the size of polyps ranges from 1.1 to $2.7 \mathrm{~mm}$ and the polyp density ranges from 2.5 to 6 polyps per $1 \mathrm{~cm}$.

Species of the genus Parantipathes are known from sublittoral and bathyal depths from the oceanic rises and continental slopes of all oceans except the Arctic (Fig. 4). Most of species are known from depths of $300-500 \mathrm{~m}$ to $900-1100 \mathrm{~m}$ (see Table 1). The only relatively shallow-water species are $P$. larix (Esper, 1790), which has been reported from depths of 20-200 m and P. tetrasticha Pourtales, which occasionally is found at depths less than 200 m (Opresko, 1972; Cairns et al., 1993).

Very little information is available on the geographical distribution of species of the genus Parantipathes. Three species, $P$. laricides, $P$. wolffi and $P$. euantha, are known only from their type localities. Four other species have a wider distribution. P. tetrasticha has been reported from the Florida Keys, off Dry Tortugas, off SE Louisiana, and from off the Yukatan Peninsula, Puerto-Rico, and Guyana (Opresko, 1972; Cairns et al., 1993). P. helicosticha was originally described from the Great Australian Bight and SE off Tasmania. In the collection of P.P. Shirshov Institute of Oceanology RAS there are two specimens of $P$. helicosticha from Valdivia seamount (SE Atlantic, $26^{\circ} 10.5^{\prime} \mathrm{S}$ $6^{\circ} 21.8 \mathrm{E}, 575-630 \mathrm{~m}$ ). The most wide geographical distribution, covering the Mediterranean Sea, NE Atlantic and IW Pacific was reported for P. larix (Brook, 1889; Roule, 1905; van Pesch, 1914). However, recently (Molodtsova, 2006) it was shown that specimens named in a number of reports from the NE Atlantic (Roule, 1905; Hickson, 1907; Gravier, 1921; Grasshoff, 1981) as P. larix represent in fact a new species, $P$. hirondelle, characterized by shorter pinnules, smaller polyps and more densely set spines. The specimen reported by Thomson (1907) from off the Faeroe Islands as $P$. larix cannot be identified as $P$. hirondelle or as $P$. larix because of its lower density of spines per $1 \mathrm{~mm}$ and also because it has a densely branched corallum. There are even some doubts that it belongs to the genus Parantipathes as defined by Opresko (2002). The specimens reported from the Indo-Pacific region by van Pesch (1914) seem to belong in fact to Parantipathes helicosticha Opresko, 1999, which has more rows of pinnules (up to five). The specimens reported as $P$. larix from the Faeroe Islands and Indo-Pacific regions are indicated on the map (Fig. 4) with a question mark. So far the only reliable location for $P$. larix is the Mediterranean Sea. There is also an undescribed species of Parantipathes in the collection of P.P. Shirshov Institute of Oceanology which was collected in the Sea of Okhotsk and in the vicinity of Unimak Island (Alaska) at depths about 850-1100 m. However, additional material is needful to adequately describe this later species.

\section{Key tO SEVEn SPECIES OF THE GENUS PARANTIPATHES}

1(2) Corallum is densely branched to $4-5^{\text {th }}$ order . P. wolffi

2(1) Corallum is monopodial or sparsely branched

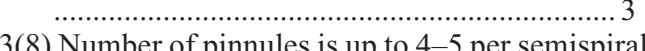
group ........................................................ 4

4(5) Pinnules are 3-4 cm long ......... P. tetrasticha

5(4) Pinnules are up to $1.8-2.0 \mathrm{~cm}$..................... 6

6 (7) Total number of pinnules per $1 \mathrm{~cm}$ is $33-40$, density of pinnular spines is $9-10$ per $1 \mathrm{~mm}$ in one row $P$. hirondelle

7(6) Total number of pinnules per $1 \mathrm{~cm}$ is up to 25 , density of pinnular spines is $2-4$ per $1 \mathrm{~mm}$ in one row .................................... P. helicosticha

8(3) Number of pinnules is up to three per semispiral group

9 (10) Pinnules up to $2 \mathrm{~cm}$ long, arranged in close clusters .................................... P. laricides

10(9) Pinnules more than $3.0 \mathrm{~cm}$ long, arranged in more or less clear semispiral groups ..........11

11(14) Pinnules up to 3-4 mm long, arranged biserially 12

12(13) Polyps $2.5-3.5$ per $1 \mathrm{~cm}$; spines triangular, perpendicular to the axis, 3.0-3.5 per $1 \mathrm{~mm}$......................................... P. euantha

13(12) Polyps 4-5 per $1 \mathrm{~cm}$; spines triangular, inclined distally, 4-6 per $1 \mathrm{~mm}$.... P. tetrasticha

14 (11) Pinnules up to 6-12 $\mathrm{cm}$ long, distributed equidistantly around the stem, biserial arrangement is not distinct P.larix

\section{Acknowledgements}

We gratefully acknowledge Dennis Opresko (Oak Ridge National Laboratory) and Andrey Gebruk (P.P. Shirshov Institute of Oceanology) for their comments to the manuscript and also we would like to thank Nancy Voss, curator of RSMAS collection for permission to study specimens of $P$. tetrasticha. 


\section{References}

Brook G. 1889. Report on the Antipatharia collected by H.M.S. Challenger during the years 1873-1876 // Report on the scientific results of the voyage of H.M.S. Challenger during the years 1873-76. Zoology. Vol.32. 222 p.

Cairns S.D., Opresko D.M., Hopkins T.S., Schroeder W.W. 1993. New records of deep-water Cnidaria (Scleractinia \& Antipatharia) from the Gulf of Mexico // Northeast Gulf Science. Vol.13. No.1. P.1-11.

Grasshoff M. 1981. Die Gorgonaria, Pennatularia und Antipatharia des Tiefwasser der Biskaya (Cnidaria, Anthozoa) // Ergebnisse der französischen Expeditionen Biogas, Polygas, Geomanche, Incal, Noratlante und Fahrten der "Talassa". II. Taxonomischer Tei // Bulletin du Museum d'Histoire Naturelle, Paris. S.4. T.3. Sect. A (4). P.941-978.

Grasshoff M. 1985. Die Gorgonaria und Antipatharia de Grossen Meteor-Bank und der Josephine-Bank (Cnidaria: Anthozoa) // Senckenbergiana maritima. Bd.17. H. $1 / 3$. P.65-87.

Grasshoff M. 1989. Die Meerenge von Giblartar als Faunen-Barriere: Die Gorgonaria, Pennatularia und Antipatharia der BALGIM-Expedition (Cnidaria: Anthozoa) // Senckenbergiana maritima. Bd.20. H. 5/6. P.201-223.

Gravier Ch. 1921. Antipathaires provenant des Campagnes des yachts Princesse-Alice et Hirondelle I (1903-1913) // Résultats des Campagnes Scientifiques accomplies sur son yacht par Albert Ier Prince de Monaco T.59. P.1-30.

Hickson S.J. 1907. The Alcyonaria, Antipatharia, and Madreporaria collected by the «Huxley» from the North Side of the Bay of the Biscay in August 1906 // Journal of the Marine Biological Association of the United Kingdom. Vol.8. P.6-14.

Molodtsova T.N. 2006. Black corals (Antipatharia: Anthozoa: Cnidaria) of North-East Atlantic // Mironov A.N., Gebruk A.V. (eds). Biogeography of the North Atlantic seamounts (in press)
Opresko D.M. 1972. Redescriptions and reevaluations of the antipatharian described by L.F. de Pourtalès // Bulletin of Marine Science. Vol.22. P.950-1017.

Opresko D.M. 1999. New species of Anthipathes and Parantipathes (Cnidaria: Anthozoa: Antipatharia) from coastal waters of South Australia and Tasmania // Records of South Australian Museum Vol.32. P.143-154.

Opresko D.M. 2002. Revision of the Antipatharia (Cnidaria: Anthozoa. Part II. Schizopathidae. // Zoologische Mededelingen. Leiden. Bd.76. P.411-442.

Opresko D.M., R.C. Baron-Szabo 2001. Re-description of the antipatharian corals described by E.J.C. Esper with selected English translation of the original German text (Cnidaria, Anthozoa, Antipatharia) // Senkenbergiana biologica. Bd.81. P.1-21.

Pasternak F.A. 1958. [Deep-sea antipatharians of KurileKamchatka Trench] // Trudy Instituta Oceanologii Vol.27. P.180-191 [in Russian].

Pasternak F.A. 1976. [New data on the composition and distribution of the deep-sea antipatharians (Hexacorallia: Antipatharia) in the Pacific, Indian, and Atlantic Oceans] // Trudy Instituta Oceanologii Vol.99. P.45-58 [in Russian, with English summary].

Pasternak F.A. 1977. Antipatharia. Galathea Report // Scientific Results of the Danish Deep-Sea Expedition round the world 1950-52. Vol. 14. P. 157-164.

Pasternak F.A. 1985. [Specific composition and the ways of forming of the bottom fauna of isolated underwater rises. Gorgonians and antipatharians of the seamounts rockway, Atlantis, Plato, Great-Meteor and Josephine (Atlantic Ocean)] // Trudy Instituta Oceanologii. Vol.120. P.21-38.

Van Pesch A.J. 1914. The Antipatharia of the Siboga Expedition // Siboga-Expeditie. Monogr.17. P.1-258.

Roule L. 1905. Description des Antipathaires et Cérianthaires recuellis par S.A.S. le Prince de Monaco dans l'Atlantique nord // Résultats des Campagnes Scientifiques accomplies sur son yacht par Albert Ier Prince de Monaco. T.30. 100 p.

Thomson J. A. 1907. Note on a large antipatharian from the Færoes // Proceedings of the Royal Society of Edinburg. Vol.17. P.188-194. 